\title{
THE PRINTERS OF SHAKESPEARE'S PLAYS AND POEMS.
}

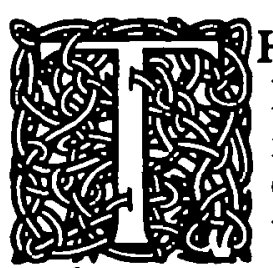

HE men who, during Shakespeare's lifetime, printed his ' Venus and Adonis,' ' Lucrece,' and 'Sonnets,' and the Quarto editions of his plays, can hardly with one exception, there is no evidence that he ever authorized the printing of any of his works, or ever revised those that were published. Even in the case of Richard Field, the evidence is presumptive and not direct. Yet Englishmen may be pardoned if they cling to the belief that Shakespeare employed Field to print for him and frequented the printing office in Blackfriars while the proof sheets of "Venus and Adonis' and 'Lucrece' were passing through the press. For Stratford-on-Avon claimed both the printer and the poet, and if it be a stretch of the imagination to look upon them as fellow scholars in the grammar school, and playmates in the fields, their distant Warwickshire birthplace offered a bond of sympathy which might well draw them to one another.

It is some matter for congratulation that the first of Shakespeare's writings to be printed came from a press that had long been known for the excellence of its work. When Richard Field came to London in 1579, be entered the service of a bookseller, but 


\section{I50 PRINTERS OF SHAKESPEARE'S}

within a year he was transferred, probably at his own desire, to the printing office of Thomas Vautrollier, the Huguenot printer in Blackfriars. He could not have found a better school. Vautrollier's office was stocked with a varied assortment of letter, so that he was capable of printing anything from a folio downwards. His type was also kept in good condition, and his workmen were skilled and competent. To this business Field succeeded, on the death of Vautrollier in 1587 , by the simple expedient of marrying the widow.

It was on the 18th April, I 593, a few days before the twenty-ninth anniversary of Shakespeare's birth, that Richard Field entered in the Registers of the Company of Stationers 'a booke intituled Venus and Adonis.' It appeared as a quarto of twenty-seven leaves, and bore on the title-page one of the smaller of the anchor devices which had formerly belonged to Vautrollier. The imprint stated that the work was to be sold at the 'white greyhound' in St. Paul's Churchyard, the address of John Harrison the elder, to whom Richard Field transferred his copyright in the poem in the following year (1594) and for whom he printed a second edition in that year, differing in nothing but the type. John Harrison the elder also entrusted to Field's press in 1594 the manuscript of 'The ravyshment of $\mathrm{Lu}$ crece.' This was issued as a quarto, with the simple title of 'Lucrece,' and differed little in appearance from the two editions of 'Venus and Adonis.' A larger and better type was used in the text, and a larger form of the anchor device was placed on the title-page. Harrison's name was also mentioned in 
the imprint. A comparison of the several copies of 'Lucrece' show that it was corrected while passing through the press, and it is a pardonable though unwarranted belief that these corrections were made by Shakespeare. Richard Field printed a third edition of 'Venus and Adonis' for John Harrison the elder, in octavo, in 1596, and with that his connection with the dramatist's work ended, though he continued in business until his death in 1624 , and rose to the highest position in his guild. As a printer he does not seem to have been so skilful or so careful as Thomas Vautrollier, yet, if we could wish these poems of Shakespeare better printed, judged by the standard of those days, Field had no cause to be ashamed of them.

A very different story has to be told in dealing with the printing of Shakespeare's plays. Pick up what one you will and its distinctive features will probably be bad paper, wretched type, and careless and slovenly press-work. This was largely due to the low condition to which the printing trade had been reduced by the monopoly system, which put all the best paying work into the hands of half a dozen men, while the majority of the printers, whose numbers were increasing year by year, found it nearly impossible to make a living by their trade. ${ }^{1}$ The printers were thus compelled to seek work that was out of the reach of the monopolists. Of such a nature were plays, and one can almost pieture

1 One of the worst of these monopolies and one of which we shall hear more, was that which prevented all but a seled few from printing the 'Grammar' and 'Accidence,' two school books that were in constant demand. 


\section{PRINTERS OF SHAKESPEARE'S}

a crowd of hungry publishers and printers haunting the theatres and worrying authors, managers, and actors for any sort of copy of the piece which was then holding the boards. As showing the class of men to whom we owe the printed editions of Shakespeare's plays, it may be stated that not one of them ever rose to any high position in the Company to which they belonged. They were chiefly distinguished for their unruly behaviour and disregard of Royal proclamations and Star Chamber decrees.

The first play of Shakespeare's that appeared in print was the tragedy of 'Titus Andronicus.' This came from the press of JOHN DANTER, a printer in a small way of business in Duck Lane near Smithfield. Danter's life was a short and troubled one. The son of an Oxfordshire man, he came to London and entered the service of the great printer John Day, in March, 1582, being bound apprentice for eight years; but before half that term was out he was found helping to print the 'Grammar' and 'Accidence' at a secret press, and so serious a view did the Wardens of the Stationers' Company take of his offence that they disabled him from ever becoming a master printer. A year or two later the severity of this sentence was relaxed, the Court of Assistants admitting the offender into partnership with William Hoskins and Henry Chettle, with whom he shared premises in Fleet Street. The partnership was of short duration, and in 1592 Danter began printing on his own account. On the 6th February, $159 \frac{3}{4}$, he entered in the registers 'a booke intituled A Noble Roman Historye of Tytus An- 
dronicus.' Until last year no edition of so early a date had been seen since the time of Langbaine, and the entry was supposed to relate to a non-Shakespearian play. But in 1905 a Swedish gentleman discovered amongst his books a quarto of this play, with the imprint, 'London, Printed by John Danter, and are to be sold by Edward White and Thomas Millington, at the little North door of Paules at the signe of the Gunne I 594.' This unique quarto was sold to an American collector, it is said, for $\oint_{0}, 000$.

Three years later John Danter also printed 'An excellent conceited Tragedie of Romeo and Juliet,' and never was a masterpiece ushered into the world in a worse manner. The printer started with a type which, in spite of its worn condition, was fairly readable, but before he had half finished the work, he substituted a very much smaller and even more worn fount. The compositors' work was of the worst description, reversed letters and mis-readings being sprinkled over every page. And with this we part thankfully with John Danter. He disappears in a whirlwind of official indignation and Star Chamber shrieks for daring to print those sacred volumes, the 'Grammar' and 'Accidence,' and in less than three years afterwards he died.

The next printer with whom we are concerned is another Oxfordshire man, Valentine Simmes or Symmes, to whose press we are known to owe the first quartos of 'Richard the Second' (1 597), and 'Richard the Third' (I 597), 'The Second Part of Henry IV' (1600), the first quarto of 'Much Ado about Nothing' (1600), as well as the third quarto ${ }_{11}$ of the 'First Part of Henry IV' in I604. Simmes, 


\section{I54 PRINTERS OF SHAKESPEARE'S}

on his arrival in London in 1576 , became an apprentice to a bookseller named Henry Sutton, who dealt largely in service books. But his desire being to be a printer and not a bookseller, he transferred his services to Henry Bynneman, a printer in Knightrider Street, who shared with John Day the patronage of Archbishop Parker. Bynneman died in $15^{84}$, and Simmes became a freeman of his Company in the next year. Apparently he found some difficulty in obtaining work, for the next that is heard of him is in connection with the Martin Marprelate press, for which he acted as compositor. He was arrested, with others, in 1589 , brought to London, and thrown into the Tower. Five years later, i.e., in 1 594, he is found with a printing office of his own at the sign of the White Swan in Addle or Addling Hill, one of the narrow lanes running up from the river Thames near Baynard's Castle. Simmes had been trained in a good school, and even his Shakespeare quartos bear evidence of the fact; indeed, the first quarto of 'Much Ado about Nothing' is one of the few play-books of that period that were decently printed. On the other hand, as the editors of the Cambridge Shakespeare were the first to point out, in some copies of the quarto of the 'Second Part of Henry IV' the first scene of Act III was entirely omitted. The mistake was discovered before the whole impression was printed, and the missing scene inserted on two new leaves. In order to do this the type of part of the preceding and subsequent leaves was distributed, so that there are two different impressions for the latter part of ACt II and the beginning of ACE III; Scene 2. 
In 1595 Simmes was caught printing the 'Grammar' and 'Accidence,' and his press was seized and his type melted. He was in trouble again in 1598 for disorderly printing, and after a chequered career the last heard of him is in the year 1622 , when by an order of the High Commissioners he was prohibited from working as a master printer, and was allowed a pension of $£ 4$ a year by the Company of Stationers.

A press of a much more interesting character is that of Thomas CREed, who carried on business at the sign of the Catherine Wheel in Thames Street. Thomas Creed's birthplace is unknown, but he was apprenticed to Thomas East, a printer chiefly remembered for his musical publications, and by East he was made a freeman on the 7 th October, 1578. Some years more elapsed before he began printing for himself, and it is not until the year 1593 that his first book-entry occurs in the registers. His office was stocked with a varied assortment of letter, most of it in good condition, and his workmanship was superior to that of many of his contemporaries. Hence we are not surprised to find amongst his earliest patrons, the great Elizabethan publisher, William Ponsonby, who endeavoured as far as possible to produce good books in a good style, and for whom Creed printed amongst other things Robert Greene's 'Mammilia,' Macchiavelli's 'Florentine History,' and Edmund Spenser's 'Colin Clout's come home again.' Indeed, much of the best of Elizabethan literature came from his press.

But it is with Creed's Shakespeare work that 


\section{PRINTERS OF SHAKESPEARE'S}

we are more particularly concerned. In 1594 he entered in the register of the Stationers' Company, and printed shortly afterwards, three books which have more than passing interest for Shakespeare students. These were "The First Part of the Contention betwixt the two famous houses of York and Lancaster,' ' The True Tragedie of Richard the Third,' and 'The Famous Victories of Henry V.' The first of these was the old play upon which Shakespeare founded 'The Second Part of King Henry VI.' This quarto bore on the title-page the printer's well-known device of Truth crowned, but stript and being beaten with a scourge held by a hand issuing from the clouds. This is repeated on the last leaf with a colophon beneath it. Except for irregular casting the type used in printing this is above the average, whilst the arrangement of the title-page was distinctly good. 'The True Tragedie of Richard the Third' was printed for William Barley, probably from the acting copy used by the 'Queenes Majesties players.' The third play, ' The Famous Victories of Henry V'-the entry of it stands in the registers next to that of 'Lucrece' -had also belonged to the Queen's players. This was the original upon which Shakespeare drew for the first and second parts of 'Henry IV,' and the play of 'Henry V.' Nineteen years after the first nown edition ( 1598 ), another appeared in 1617 , printed by Creed's successor, Bernard Alsop, for Timothy Barlow.

In 1595 Creed entered and printed apparently on his own account, 'The Lamentable Tragedie of Locrine, Newly set forth, overseene and cor- 
rected by W. S.,' no doubt thinking that the initials would find it a ready sale, until some one troubled to point out that Shakespeare had nothing to do with it.

Creed's first genuine Shakespeare quarto was the second edition of 'Richard III,' which he printed for Andrew Wise in I 598. In the next year (1 599) the second quarto of 'Romeo and Juliet' came from his press at the instance of Cuthbert Burby, its lawful owner, and in 1600 he put to press for Thomas Millington and John Busby 'The chronicle history of Henry the fift.' The first quarto of 'The Merry Wives of Windsor,' the second quarto of ' Henry V,' and the third quarto of 'Richard III,' all came from his press in 1602, and from that time onwards till 1612 , he continued to print editions of both 'Richard III' and 'Henry V.' Good workman as he could be when he liked, most of these quartos of Creed's are very little better than those issued by his brother printers. In 1616 he took into partnership Bernard Alsop, who in the following year succeeded to the business on the retirement or death of Creed.

The same year that saw the publication of ' $\mathrm{Lu}$ crece' and the three non-Shakespearean plays just noticed, and about the same time-that is, in May, 1594-another printer, named PETER SHORT, entered in the Register a play called 'A merrie conceyted comedie of the 'Taming of a Shrew.' This entry is held to relate to an older play dealing with the same subject, and at present Peter Short's connection with Shakespeare's work is limited to the first 11. quarto of 'The First Part of Henry IV', printed 


\section{58 PRINTERS OF SHAKESPEARE'S}

by him for Andrew Wise in 1598 . The general appearance of this book is good. The title-page is neatly arranged and printed with fairly regular founts of roman and italic, while above the imprint is the printer's device of the star. The type of the text is also much clearer, and the workmanship above the average. But although this was the only work of Shakespeare's ever put into Short's hands, he was the printer of that famous Elizabethan notebook, Francis Mere's 'Palladis Tamia,' renowned for its Shakespeare allusions. This dumpy little octavo is also printed throughout in a clear and regular fount of roman. The printer's history may be briefly outlined. Admitted a freeman of the Company of Stationers in 1589 , Short succeeded to the printing business of Henry Denham, whose device of the star he adopted as his sign when he set up his printing office in Bread Street Hill, near St. Paul's. From the fact of his name appearing in a list of printing houses, upon which the Archbishop of Canterbury and the Bishop of London directed that watch should be kept for prohibited books, it would seem that Short, like many of his brother printers, was given to illicit printing. In addition to the two books noticed above, several notable works came from his press, including a number of musical publications. He died in 1603 , probably from the plague, which was very deadly in London in that year, and his business passed into the hands of Humphrey Lownes.

Another Shakespeare issue of the year 1598 was 'Love's Labour's Lost,' printed by 'W. W. for 
Cuthbert Burby.' The initials stand for WiLliam White, a small printer th $\mathrm{n}$ living in Smithfield, whose principal trade lay in ballads and broadsides, and who was fined five shillings on one occasion for printing a lewd ballad called 'The Wife of Bath.' This quarto of 'Love's Labour 's Lost' may be taken as a fair specimen of his work, which was about as bad as it could be. His initials are also found on the title-page of the second quarto of ' The True Tragedie of Richard, Duke of York,' otherwise 'The Third Part of King Henry VI,' which he printed for Thomas Millington in I600, and again in the fifth quarto of 'The First Part of Henry IV,' printed in 1613 for Mathew Law.

The second quarto of this same play, which was issued in 1599 , introduces us to Simon Stafford, whose initials, S. S., are in the imprint as printer for Andrew Wise. A chapter might well be written about this man's history. He belonged to the guild of Drapers, but choosing to be a printer, was apprenticed to Christopher Barker, the royal printer, who was also a member of the Drapers' Company. Stafford set up a press in Black Raven Alley, in the parish of St. Peter's, Cornhill, in 1597, but on the 1 $3^{\text {th }}$ March, 1598, the Stationers seized his press and letters, declaring that they had found 4,000 copies of the 'Grammar' and 'Accidence' on his premises. Stafford's offence was aggravated by his being a draper, and it was not until he transferred himself to the Company of Stationers that he was allowed to carry on the trade of a printer. In addition to the quarto of 'Henry IV,' he also printed the 16 I 1 edition of 'Pericles.' 


\section{PRINTERS OF SHAKESPEARE'S}

None of the presses that have been noticed, not even that of Thomas Creed, equals in interest that which next comes under consideration-the press of JAMrs RoBrRTs. We are undoubtedly indebted to it for the first quartos of 'A Midsummer Night's Dream' and 'The Merchant of Venice,' the second quarto of 'Titus Andronicus,' all three printed by him in 1600 , and also for the second and third quartos of the tragedy of 'Hamlet,' printed in the years 1604 and 1605 . Admitted a freeman of the Company of Stationers in 1564 , Roberts seems to have set up in Fleet Street under the sign of 'Love and Death; and for some years devoted himself mainly to the printing of ballads. He then joined partnership with a certain Richard Watkins, and they obtained a royal patent for the sole printing of almanacs and prognostications, which must have been a very lucrative business. In 1593 Roberts married the widow of John Charlwood, a printer at the sign of the Half Eagle and Key in the Barbican. Charlwood appears to have had a large stock of type, blocks, and devices, to which Roberts afterwards added considerably. Charlwood's copyrights also were numerous, though chiefly of a theological character. Roberts seems to have launched out in an entirely new direction, and within the next twelve years printed works by Nicholas Breton, Daniel, Drayton, Gabriel Harvey, Lyly, Marston, Nash, Spenser, and Shakespeare. Which of the three Shakespeare quartos printed by Roberts in the year 1600 is the earliest it would be rash to say, as the 'Titus Andronicus' had been entered in the Registers on the appearance of the first edition in 
1594. There were also two issues of each of the other plays, both bearing different imprints. One quarto of the 'Midsummer Night's Dream' has no printer's name, but simply the statement that it was printed ' for Thomas Fisher,' but there is no doubt that both were printed by Roberts. In the same way there were two quartos of 'The Merchant of Venice,' one the outcome of the licence granted to Roberts on 22nd July, 1598, and the other following upon his transfer of the copyright to 'Thomas Haies.' On the title-page of the Roberts quarto of the 'Merchant' is seen the device of Richard Johnes, another London printer of this date, and at the end of it the tail-piece of the woman's head and cornucopiae, which certainly once belonged to Richard Field, and is found in his books up to this period. How and when it came into the hands of James Roberts are questions that need further investigation, but cannot be dealt with here. The 'Fisher' edition of the 'Midsummer Night's Dream' has that publisher's device of the kingfisher on the title-page, and the ornament at the end tells us nothing; whereas the Roberts copy has Charlwood's old block of the Half Eagle and Key above the imprint. The points in common between the two are the ornament or band at the head of the first page of the text and the similar type.

In or about 1608 -the exact date is unknown - James Roberts sold his business to William Jaggard, who, until this time, had been trading as a bookseller in the Churchyard of St. Dunstan's-inthe-West, and who now added that of a printer to vII. 


\section{I62 PRINTERS OF SHAKESPEARE'S}

his business. Jaggard's connection, and that or his son Isaac, with the First Folio or 1623 has been so often described that there is no need to repeat it here.

The only other hitherto recognized printer of the first edition or any work by Shakespeare during his life is George Eld, from whose press, in I 609, came the 'Sonnets' and 'Troilus and Cressida.' Eld was a Derbyshire man, who in 1593 had put himselt apprentice to a stationer for eight years, but was admitted a freeman of the Company two years before the expiration of his time, a most unusual proceeding. He was a capable printer, many of his books being amongst the best specimens of typography of the Elizabethan time. To name only one example, 'Grimstone's General Historie of the Netherlands ' is a very handsome folio in which the types and presswork are exceedingly good. Unfortunately the same cannot be said for the 'Sonnets,' which was marred by being printed in a diminutive fount of roman that did not print well, nor was the quarto of 'Troilus and Cressida' a much better performance.

In 16 I 4 Eld took into partnership Miles Flesher or Fletcher, and in the return made in the following year they were found to have two presses, an evidence that they had an extensive business. Eld died of the plague in 1624, and was succeeded by his partner.

Having thus passed in review the printers whose names or initials are found in the imprints of the early Shakespeare quartos, I propose to say a few words as to the presses to which the editions without im- 
prints may be assigned. The first of these is the maimed and mutilated first quarto of 'HAMLET.' Only the publishers' names-Nicholas Ling and John Trundle-are given on the title-page, and the device which decorates it is that of Ling. The type is not good, and the press work supports the theory that the book was hastily rushed through the press. The ornament at the top of the first page of text is one used by Valentine Simmes, but I was nevertheless at first inclined to attribute the edition to the press of Roberts, to whom the play had been licensed the previous year, and who seems to have been fond of acquiring ornaments which had been used by other printers. Mr. Pollard, however, who had been independently investigating the question as to the printing of the play, produced me a book, the 'Earl of Gowrie's Conspiracy,' printed by Simmes in 1603 , in which this particular ornament occurred, and to the press of Simmes the first edition of ' Hamlet' must therefore be assigned.

We may next consider to whose typography we owe the two quartos of 'KING LEAR,' which appeared in 1608 , both without any indication of the printer. In one the imprint is simply "Printed for Nathaniel Butter I 608,' while in the other it takes the longer form, 'London, Printed for Nathaniel Butter, and are to be sold at his shop in Paul's Church-yard at the signe of the Pide Bull neere St. Austin's Gate, 1608.' The first-named issue has on the title-page above the imprint the device of Richard Johnes, and at the top of A 2 a woodcut ornament, both of which identify it as coming from the press of James Roberts, though whether in 1600 


\section{PRINTERS OF SHAKESPEARE'S}

Roberts was still the owner of it we cannot be quite sure. The Pide Bull issue is not so easily identified. The most obvious available clue is the curious device above the imprint of a rod, round which two snakes are wound, and which is fitted with wings at the top and bottom, held at the bottom by two hands issuing from clouds. Cornucopiae also form a part of the design, which is surmounted by a winged horse. This device had come from abroad, having once belonged to Andreas Wechelin of Frankfort, and was used by him in printing ' Petri Rami commentariorum de religione Christiana libri quatuor 1576,' the title-page of which is amongst those collected by Ames (B.M. 463, h. 8, 461). In I600, this device is found in an English book, William Covell's Brief Answer unto Certaine Reasons by way of an Apologie delivered to ... the ... bishop of Lincolne by Mr. Iohn Burges ...' with the imprint 'At London Printed by G. S. for Clement Knight, and are to be sold at his shop in Pauls Churchyard at the signe of the Holy Lambe. 1606.'

It will further be noticed that the Pide Bull copy has at the top of sig. B a narrow band of conventional pattern, with a man's face in the centre, which will be found again at the top of the titlepage of the English translation of William Bucanus' 'Institutions of Christian Religion,' printed at London, by George Snowdon and Leonell Snowdon in 1606 (B.M. 874, C 10); ${ }^{1}$ while on sig. $\mathrm{A}_{3}$ of the 'Briefe Answer' will be found a large pierced

1 There is a better impression of this title-page amongst the Ames colletion. 
woodcut initial letter, which is used more than once in the Institutions (see $\mathrm{Kk}_{3}$ recto, $\mathbf{M m}$ verso):

But who were George and Leonell Snowden? According to the Registers, George Snowden was entered as an apprentice to Robert Robinson on the 27th April, I 590; but this entry has a marginal note that George was Singleton's apprentice and that Robinson was to 'put him away' within seven days, an order he does not seem to have obeyed, as George Snowden was presented by him for his freedom on the I Ith May, I 597. Leonell or Lionell Snowden was evidently a relative, but not a brother of George's. He, too, was an apprentice to Robinson, being out of his time in February, 1604 . Some time in 1606 , the year of the publication of the 'Brief Answer' and 'Institutions' the two Snowdens appear to have had an interest for a short time in a printing business of John Harrison the youngest who died in 1604, and who in his turn had succeeded to the business of Thomas Judson. In Sir John Lambe's memoranda, printed in Vol. III of the ' Transcript' (pp. 669, et seg.), either Mr. Arber has made a mistake in transcribing the names, or Sir John Lambe got confused, as well he might, between the Snowdens and the Snodhams. In any case their career was a very short one, and there is not a single book entered to either of them in the Registers.

Further, according to these same memoranda of Sir John Lambe's, the Snowdens, in 1608 , the year of the publication of ' King Lear,' transferred their business to Nicholas Oakes or Okes. Now Nicholas Okes had taken up his freedom in 1603 , and his first book entry in the Registers was in July, 1607. 
166 PRINTERS OF THE PLAYS, ETC.

It is quite possible that the 'Lear,' though it bears the date of 1608 , may have been printed towards the close of 1607 , while on the other hand though Okes had permission to print in July, 1607, he may not have bought the Snowden's interest until 1608 . The actual hand that printed it matters little, we now know that it came from the office established by Thomas Judson in 1586 , and in the hands successively of John Harrison the younger, George and Lionel Snowden, and Nicholas Okes.

A third play, the first quarto of which appeared without any hint as to the printer, was 'Pericles,' two editions of which were printed in 1609 ' for' Henry Gosson, who was "then living at the sign of the Sunne in Paternoster Row.' Both of them bear at the top of the first page of text a band easily recognized as that of William White, whose business was taken over in 1620 by Augustine Matthews, the printer of the second quarto of 'Othello' in I $63^{\circ}$ for Richard Hawkins, in which the same band is used again, and White's block of the charioteer in a very worn state is seen on the title-page.

With this attempt to identify the typographical authors of these three plays we may bid farewell to the printers of Shakespeare's plays and poems. Greatly would these good men have been surprised had they been told that their connection with these sixpenny pamphlets would be their chief title to remembrance.

H. R. Plomer. 